CZASOPISMO INŻYNIERII LA¿DOWEJ, ŚRODOWISKA I ARCHITEKTURY JOURNAL OF CIVIL ENGINEERING, ENVIRONMENT AND ARCHITECTURE JCEEA, t. XXXIII, z. 63 (4/16), październik-grudzień 2016, s. 71-77

\author{
Krystian CIEŚLAK ${ }^{1}$ \\ Alain FAVE ${ }^{2}$ \\ Mustapha LEMITI ${ }^{3}$
}

\title{
WPLYW TYLNEGO LUSTRA DIELEKTRYCZNEGO NA DZIAŁANIE KRZEMOWYCH, CIENKOWARSTWOWYCH OGNIW SŁONECZNYCH OTRZYMANYCH METODĄ EPITAKSJI Z FAZY GAZOWEJ
}

\begin{abstract}
Metoda epitaksji z fazy gazowej została użyta do wytworzenia krzemowych, cienkowarstwowych ogniw słonecznych. Emiter wyprodukowanych ogniw fotowoltaicznych był typu p i znajdował się po tylnej stronie ogniwa, a absorberem był krzem typu n. W celu obniżenia kosztów produkcji aktywnej warstwy, został użyty dwuwarstwowy krzem porowaty wytworzony na krzemie monokrystalicznym. Krzem porowaty składał się z warstwy o wysokim stopniu porowatości oraz warstwy o niskim stopniu porowatości, obecnej na powierzchni. Takie rozwiązanie pozwala na wzrost monokrystalicznej warstwy o wysokiej jakości oraz na odczepienie jej od podłoża wzrostowego i ponowne jego użycie w kolejnym procesie wzrostu epitaksjalnego. Dodatkowo w celu zwiększenia odpowiedzi ogniw słonecznych na fale elektromagnetyczne w zakresie $700 \mathrm{~nm}-1200 \mathrm{~nm}$, zostało opracowane i naniesione lustro dielektryczne składające się z warstwy $\mathrm{SiNx} / \mathrm{SiOx}$ lub pojedynczej warstwy SiNx. Warstwa aktywna wraz z naniesionym lustrem była podda badaniu na współczynnik odbicia światła o długości fali $\mathrm{z}$ w/w zakresu. W celach porównawczych zostały zbadane próbki z dwoma różnymi lustrami oraz próbka referencyjna bez lustra. Badania wykazały, że zastosowane lustro dielektryczne spełnia swoje zadanie i zwiększa współczynnik odbicia światła o ponad $70 \%$. Oznacza to, że zastosowanie w/w lustra dielektrycznego będzie miało pozytywny wpływ na współczynnik absorpcji światła w ogniwie fotowoltaicznym, co będzie się bezpośrednio przekładało na jego parametry elektryczne.
\end{abstract}

Słowa kluczowe: fotowoltaika, krzem porowaty, krzem cienkowarstwowy, właściwości optyczne

\footnotetext{
${ }^{1}$ Autor do korespondencji / corresponding author: Krystian Cieślak, Politechnika Lubelska, Instytut Inżynierii Ochrony Środowiska, Wydział Inżynierii Środowiska, ul. Nadbystrzycka 40B 20-618 Lublin; k.cieslak@pollub.pl

2 Alain FAVE, Université de Lyon, Institut des Nanotechnologies de Lyon INL - UMR5270, CNRS, Ecole Centrale de Lyon, INSA Lyon, Villeurbanne, F-69621, France

${ }^{3}$ Mustapha LEMITI, Université de Lyon, France
} 


\section{Wprowadzenie}

Dzisiejszy Świat staje przed dużym wyzwaniem związanym z utrzymaniem stabilności energetycznej. Wciąż zwiększające się zapotrzebowanie na energię elektryczną powoduje, że zasoby naturalne paliw kopalnych kurczą się w wysokim tempie, dlatego inwestycja w rozwój odnawialnych źródeł energii (OZE) wydaje się być dobrym rozwiązaniem. Takie podejście pozwala na dywersyfikacje źródeł energii, co jest ważne z punktu widzenia bezpieczeństwa energetycznego, ale również jest to podejście proekologiczne - większość technologii OZE są to technologie bez emisyjne.

Jedną z alternatywnych metod pozyskiwania energii elektrycznej jest fotowoltaika - nauka badająca bezpośrednią konwersję energii promieniowania słonecznego na elektryczność. Biorąc pod uwagę, że ilość energii docierającej ze Słońca do powierzchni Ziemi przewyższa 10000 razy zapotrzebowanie energetyczne świata [1] oraz, że z punktu widzenia ludzkości Słońce jest nieskończonym źródłem energii, ogniwa fotowoltaiczne stają się obiecującym odnawialnym, bez emisyjnym źródłem energii.

Rozwój technologii fotowoltaicznych jest bardzo dynamiczny [2] i podyktowany chęcią obniżenia kosztów wytworzenia energii elektrycznej z ogniw słonecznych. Można to osiągnąć na dwa sposoby: zwiększając wydajność baterii słonecznych, albo zmniejszając koszt ich produkcji. Ogniwa cienkowarstwowe wpisują się w ten drugi trend - poprzez zmniejszenie ilości materiału potrzebnego do wyprodukowania ogniwa słonecznego, maleje jego koszt produkcji. Oczywiście ma to swoje wady, krzem, jako najbardziej rozpowszechniony materiał $\mathrm{w}$ produkcji ogniw ma niski współczynnik absorpcji związany z ukośną przerwą energetyczną [3]. Oznacza to, że żeby efektywnie generować nośniki prądu, krzem potrzebuje większej grubości niż półprzewodniki z prostą przerwą energetyczną. Cienkowarstwowe ogniwa krzemowe mają grubość od kilku nanometrów do kilkudziesięciu mikrometrów, powoduje to, że przy projektowaniu należy wziąć pod uwagę zwiększanie drogi optycznej światła w warstwie aktywnej [4]. Można to osiągnąć przez teksturyzację powierzchni przedniej/tylnej ogniwa i/lub wytworzenie lustra na tylnej powierzchni odbijającego niskoenergetyczne fotony [5]. Taka modyfikacja pozwala na absorpcję fotonów, które w przeciwnym razie przeszłyby przez ogniwo bez interakcji [6].

Niniejszy artykuł prezentuje badania odbicia światła z zakresu $700 \mathrm{~nm}-$ $1200 \mathrm{~nm}$ od tylnej strony cienkowarstwowych, krzemowych ogniw słonecznych z dwoma rodzajami dielektrycznego lustra. Dla porównania zostały również przeprowadzone pomiary odbicia światła $\mathrm{z}$ w/w zakresu dla próbki bez lustra. 


\section{Opis procedury badawczej}

\subsection{Metody otrzymywania krzemowych, cienkowarstwowych ogniw słonecznych}

Epitaksja z fazy gazowej (Vapor Phase Epitaxy - VPE) została wybrana jako metoda nanoszenia aktywnej warstwy krzemowej [7]. Jako podłoże wzrostowe został użyty krzem monokrystaliczny o orientacji krystalograficznej (100) z podwójną warstwą krzemu porowatego. Krzem o $20 \%$ porowatości obecny na powierzchni podłoża wzrostowego pod wpływem temperatury na poziomie $1100^{\circ} \mathrm{C}$ przed wzrostem epitaksjalnym, ulega restrukturyzacji i tworzy kilku nanometrową, monokrystaliczną warstwę na powierzchni podłoża. Umożliwia to wzrost aktywnej, krzemowej warstwy o parametrach krzemu monokrystalicznego. W tym samym czasie krzem o wysokiej porowatości (75\%) pod wpływem wysokiej temperatury ulega degradacji, co w późniejszym procesie umożliwia odczepienie naniesionej warstwy od podłoża wzrostowego [8]. Po odpowiedniej procedurze czyszczenia, podłoże wzrostowe może być wykorzystane w kolejnej epitaksji.

W trakcie wzrostu epitaksjalnego zostały naniesione następujące warstwy (Rys. 1):

- $300 \mathrm{~nm}$ krzemu n+, domieszkowanego fosforem, pełniącego rolę front surface field (FSF),

- $40 \mu \mathrm{m}$ krzemu typu n, domieszkowanego fosforem - pełniącego rolę bazy,

- $3 \mu \mathrm{m}$ krzemu typu p+, domieszkowanego borem - pełniącego rolę emitera.

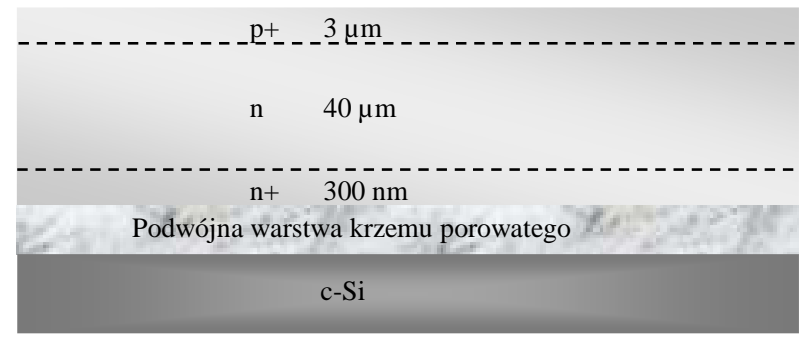

Rys. 1. Struktura aktywnej warstwy po procesie epitaksji

Fig. 1. The structure of an active layer after the epitaxy process

Aby zwiększyć drogę optyczną w cienkowarstwowym ogniwie słonecznym, korzystając z symulacji przeprowadzonych za pomocą oprogramowania IMD [9] zostało opracowane lustro dielektryczne z kombinacji dwóch materiałów - SiNx oraz SiOx $[10,11]$. Następnie w reaktorze, który umożliwia nanoszenie cienkich warstw z wykorzystaniem plazmy PECVD - Plasma Enchanced Chemical Vapor Deposition, zostały naniesione odpowiednie grubości w/w dielektryków (Rys. 2). 
$\mathrm{SiNx} / \mathrm{SiOx}$

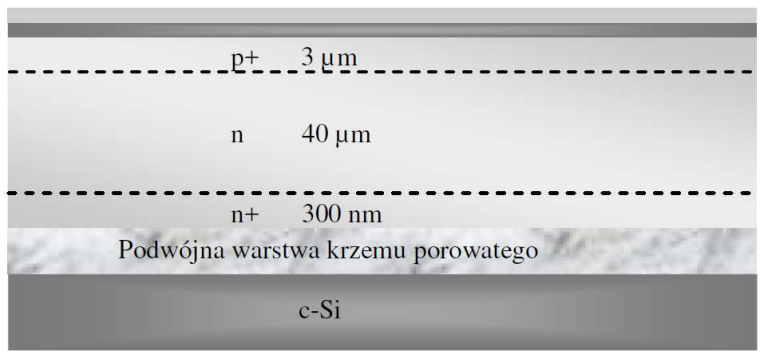

Rys. 2. Struktura próbki po procesie naniesienia lustra dielektrycznego

Fig. 2. Structure of the sample after dielectric mirror deposition

Jednocześnie korzystając z wyżej opisanej procedury, została przygotowana próbka referencyjna bez lustra dielektrycznego.

Następnie próbki zostały poddane badaniu na współczynnik odbicia światła o długości $\lambda$ z zakresu $700 \mathrm{~nm}-1200 \mathrm{~nm}$. Po porównaniu wyników, pozwoliło to na określenie wpływu lustra na współczynnik odbicia światła $\mathrm{z}$ badanego zakresu.

\section{Metodyka i wyniki badań}

Przed naniesieniem lustra dielektrycznego zostały przeprowadzone obliczenia za pomocą programu IMD, pozwalającego na symulowanie optycznych właściwości cienkich warstw. Użycie danych opisujących współczynnik załamania światła dla używanych materiałów pozwoliło na zoptymalizowanie grubości SiOx i SiNx w celu uzyskania maksymalnego współczynnika odbicia światła z zakresu $700 \mathrm{~nm}-1200 \mathrm{~nm}$ od powyższej struktury. Zgodnie z wynikami symulacji zostały zbadane dwie różne warstwy:

- pojedyncza warstwa SiNx o grubości $70 \mathrm{~nm}$,

- warstwa $\mathrm{SiOx} / \mathrm{SiNx}$ o grubości odpowiednio $110 \mathrm{~nm} / 10 \mathrm{~nm}$.

Po naniesieniu warstwy dielektryków na wcześniej przygotowane struktury krzemowe zostały przeprowadzone pomiary współczynnika odbicia światła dla w/w próbek. Wyniki zostały zaprezentowane na rysunku 3. 


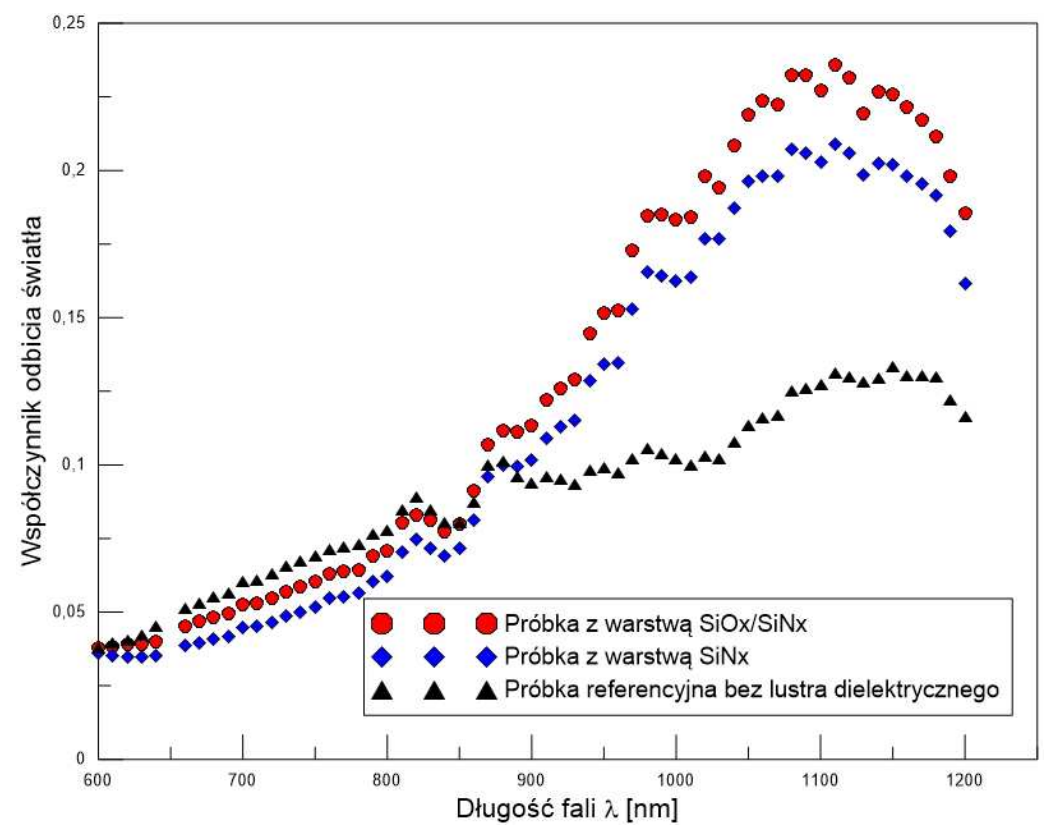

Rys. 3. Współczynnik odbicia światła od lustra dielektrycznego naniesionego na krzem w zależności od długości fali $\lambda$

Fig. 3. Reflectance from a dielectric mirror deposited on silicon

\section{Analiza wyników}

Z wykresu widocznego na Rys. 3 wynika, że wytworzone lustro dielektryczne odbija światło z zakresu długości fali $870 \mathrm{~nm}-1200 \mathrm{~nm}$, a maksimum współczynnika odbicia osiąga dla długości fali $1110 \mathrm{~nm}$. Dla struktury $\mathrm{SiOx} / \mathrm{SiNx}(110 \mathrm{~nm} / 10 \mathrm{~nm})$ maksymalny współczynnik odbicia światła osiąga wartość 0.23 , dla pojedynczej warstwy SiNx maksimum wynosi 0.2. Próbka referencyjna bez lustra dielektrycznego w opisywanym zakresie długości fali maksimum odbicia osiąga również dla $1110 \mathrm{~nm}$, a maksymalna wartość współczynnika odbicia światła przyjmuje wartość 0.13 . Z analizy przedstawionych wyników wynika, że struktura $\mathrm{SiOx} / \mathrm{SiNx}(110 \mathrm{~nm} / 70 \mathrm{~nm})$ naniesiona na tylną powierzchnię cienkowarstwowego ogniwa krzemowego będzie powodowała znaczący wzrost współczynnika odbicia światła z zakresu długości $870 \mathrm{~nm}-1200 \mathrm{~nm}$, a maksymalna różnica pomiędzy próbką z lustrem i bez lustra sięga $76 \%$ na korzyść próbki ze strukturą dielektryczną. Oznacza to, że fotony o długości fali $\mathrm{z}$ badanego zakresu po przejściu przez aktywną warstwę krzemowego ogniwa cienkowarstwowego, odbiją się od tylnej powierzchni, na której został naniesiony dielektryczny reflektor i zostaną skierowane z powrotem do warstwy aktywnej baterii słonecznej zwiększając tym samym prawdopodobieństwo absorpcji fotonów niskoenergetycznych. Oczywiście $76 \%$ wzrost współczynnika odbicia 
światła nie przełoży się na $76 \%$ wzrost prądu zwarcia ogniwa słonecznego, ale z pewnością będzie miał pozytywny wpływ na polepszenie parametrów elektrycznych cienkowarstwowych ogniw słonecznych. Dokładny wpływ prezentowanej struktury na parametry opisujące ogniwa słoneczne będzie przedmiotem kolejnych badań.

\section{Wnioski}

W zaprezentowanych badaniach zostały wytworzone za pomocą epitaksji z fazy gazowej warstwy aktywne cienkowarstwowych, krzemowych ogniw słonecznych (Rys. 1). Następnie zostały przeprowadzone symulacje komputerowych mające na celu ustalenie grubości i składu optymalnej warstwy zbudowanej z SiOx/SiNx oraz SiNx w celu zmaksymalizowania odbicia niskoenergetycznych fotonów z zakresu długości fali $700 \mathrm{~nm}-1200 \mathrm{~nm}$. Kolejnym krokiem, wykorzystując parametry ustalone podczas symulacji, było naniesienie warstw dielektrycznych za pomocą techniki PECVD mających pełnić rolę tylnego reflektora w baterii słonecznej. W celach porównawczych została również przygotowana próbka bez lustra dielektrycznego. Tak przygotowane struktury zostały poddane badaniu na współczynnik odbicia światła z zakresu $700 \mathrm{~nm}-1200 \mathrm{~nm}$.

Analiza wyników wykazała, że struktura złożona z SiOx/SiNx o grubościach odpowiednio $110 \mathrm{~nm} / 10 \mathrm{~nm}$ charakteryzuje się największym współczynnikiem odbicia światła z zakresu $870 \mathrm{~nm}-1200 \mathrm{~nm}$ i osiąga maksimum 0.23 dla długości fali $1110 \mathrm{~nm}$. Jednocześnie maksymalna różnica współczynnika odbicia światła pomiędzy strukturą z $\mathrm{SiOx} / \mathrm{SiNx}$, a próbką bez naniesionej struktury dielektrycznej sięga 76\% na korzyść próbki z lustrem dielektrycznym. Oznacza to, że obecność wewnętrznego lustra dielektrycznego wewnątrz baterii słonecznej będzie skutecznie zwiększało współczynnik absorpcji dla fotonów niskoenergetycznych, co będzie miało pozytywny wpływ na parametry elektryczne cienkowarstwowych ogniw słonecznych.

\section{Uwagi}

Zaprezentowane badania zostaty przeprowadzone dzięki francuskiemu programowi OSEO o akronimie „FASIL” oraz dzięki European KIC Innoenergy (projekt „Powcell”)

\section{Literatura}

[1] Planning and Installing Photovoltaic Systems A guide for installers, architects and engineers, second edition. German Solar Energy Society (2008). Berlin: Routledge, 2008.

[2] https://www.ise.fraunhofer.de/en/renewable-energy-data/renewable-energy-data\#ttitlea996f24a58e8a95dd6842ca79fd0d698 \{dostęp 23.05.2016\}.

[3] Gray J.: The Physics of the Solar Cell. A. In A. Luque and S. Hegedus Handbook of Photovoltaic Sci-ence and Engineering. West Sussex: Wiley 2003. 
[4] Jóźwik I., Kraiem J., Olchowik J. M., Fave A., Szymczuk D., Zdyb A.: Epitaxial Lateral Overgrowth of Si on Patterned Si Substrates by Liquid Phase Epitaxy, Molecular Phys. Rep. 39, 2004, s. 85-89.

[5] http://pveducation.org/pvcdrom/design/surface-texturing \{dostęp 23.05.2016\}.

[6] Ivanov I., Nychyporuk T., Skryshevsky V., Lemiti M.: Thin silicon solar cells with SiOx /SiNx Bragg mirror rear surface reflector. Semiconductor Physics, Quantum Electronics \& Optoelectronics, 12, 2009, s. 406.

[7] Levy F.: Film Growth and Epitaxy: Methods. Encyclopedia of Condensed Matter Physics, 2005, 210.

[8] Radhakrishnan H., Martini R., Depauw V., Nieuwenhuysen K., Bearda T., Gordon I., Szlufcik J., Poortmans J.: Kerfless layer-transfer of thin epitaxial silicon foils using novel multiple layer porous silicon stacks with near 100\% detachment yield and large minority carrier diffusion lengths, Solar Energy Materials \& Solar Cells, 135, 2015, s. 113.

[9] Windt D. L.: IMD-Software for modeling the optical properties of multilayer films. Comput. Phys. 12, 1998, s. 360.

[10] Heiss W., Schwarzl W., Roither T., Springholz J., Aigle G., Pascher M., Biermann H., Reimann K.: Epitaxial Bragg mirrors for the mid-infrared and their applications. Progress in Quantum Electronics 25, 2001, s. 193.

[11] Olchowik J.M., Gułkowski S., Cieślak K., Jóźwik J., Kaminski A., Fave A.: Analisys of internal reflectivity of silicon ELO PV cells obtained by LPE, Photovoltaic Specialists Conerence (PVSC), 2010 35th IEEE, s. 3546 - 3548.

\section{INFLUENCE OF A BACK SIDE DIELECTRIC REFLECTOR ON THE THIN SILICON SOLAR CELLS PERFORMANCE}

Vapor phase epitaxy (VPE) method was used to fabricate thin film silicon solar cells. Active layer was build with $\mathrm{p}$ type back side emitter, $\mathrm{n}$ type absorber and $\mathrm{n}+$ type front surface field (FSF). In order to reduce costs of production double porous silicon structure was fabricated on a monocrystalline silicone. Porous silicon had a one low porosity layer on the top of a growth substrate and high porosity area just underneath the low porosity film. That kind of structure enabled to perform growth of a monocrystalline epitaxial silicon layer. During growth, the high porosity area was degraded due to a high temperature treatment and after the process detachment of an active layer was possible. After additional cleaning seed substrate can be reused in another VPE process. In order to increase spectral response of fabricated solar cells to low energy photons from a wavelength range $700 \mathrm{~nm}-1200 \mathrm{~nm}$, dielectric mirror was developed and deposited. Two structures were checked - double layer build with $\mathrm{SiOx} / \mathrm{SiNx}$ and one layer of SiNx. Active layer grown by means of VPE with a dielectric mirror deposited was examined in order to establish reflectivity from a given structures. In order to make comparison, reference sample was fabricated. It had the same structure of an active layer but there was no dielectric mirror deposited. Analysis of the results showed that the dielectric mirror works as expected and reflectivity in a wavelength range $700 \mathrm{~nm}-1200 \mathrm{~nm}$, is more than $70 \%$ higher for the structure with the dielectric mirror compared to the reference sample. It means that proposed solution would increase the absorbance inside the material and would have a positive influence on the thin silicon solar cells performance.

Keywords: photovoltaic, porous silicon, thin film silicon, optical properties

DOI:10.7862/rb.2016.249

Przestano do redakcji: $30.06 .2016 r$.

Przyjęto do druku: 20.12.2016 r. 
